\title{
MEKANISME PASAR ISLAMI
}
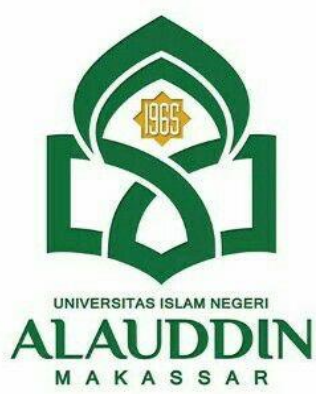

MAKALAH

Diseminarkan Pada Mata Kuliah Ekonomi Mikro Islam Program Studi

Perbankan Syariah Semester III Tahun 2021

Oleh :

Kelompok 11

Nurbaiti

(90500120010)

Asmila Dewi

(90500120018)

Muhajir

(90500120040)

Dosen Pengampu:

Samsul Arifai, S.A.B., M.A

PROGRAM STUDI PERBANKAN SYARIAH

FAKULTAS EKONOMI DAN BISNIS ISLAM

UIN ALAUDDIN MAKASSAR

2021 


\section{KATA PENGANTAR}

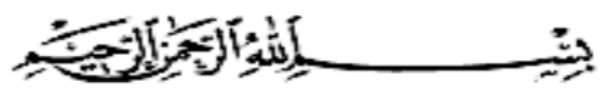

Puji syukur penulis panjatkan ke hadirat Allah swt. Atas rahmat dan hidayahNya sehingga penyusunan tesis ini dapat diselesaikan. Shalawat dan salam semoga tercurahkan kepada Nabi Mauhammad saw, keluarga dan para sahabatnya. Makalah dengan judul: "Mekanisme Pasar Islami” ini dimaksudkan untuk memenuhi salah satu syarat lulus pada mata kuliah ekonomi mikro Islam. Penulis menyadari bahwa penyelesaian makalah ini tidak akan terwujud tanpa bantuan, bimbingan dan dukungan dari berbagai pihak.

Gowa, 24 November 2021

Penyusun 


\section{DAFTAR ISI}

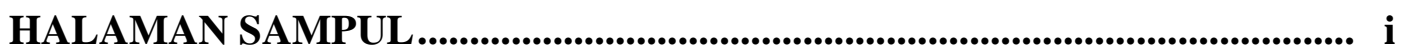

KATA PENGANTAR ........................................................................... ii

DAFTAR ISI.............................................................................................. ii

BAB I PENDAHULUAN ................................................................................. 1

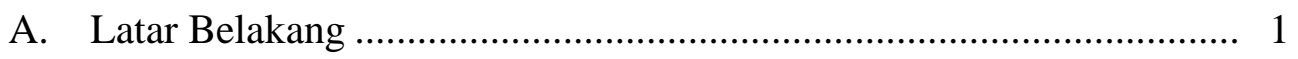

B. Rumusan Masalah ....................................................................... 2

C. Tujuan dan Manfaat Penelitian .............................................................. 2

BAB II PEMBAHASAN ........................................................................................ 3

A. Pasar di Masa Rasulullah ............................................................... 3

B. Pandangan Ekonom Muslim ............................................................... 8

C. Peranan Pemerintah dalam Mengawasi Pasar ........................................2 21

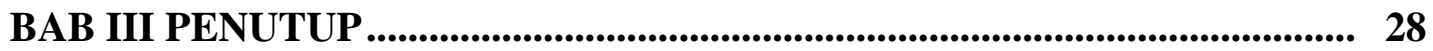

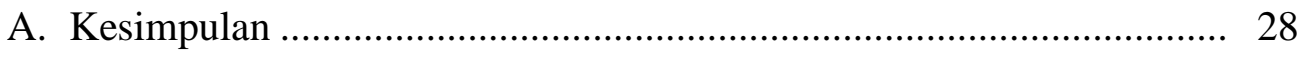

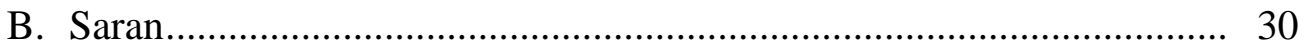

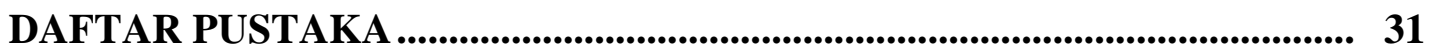




\section{BAB I}

\section{PENDAHULUAN}

\section{A. Latar Belakang}

Islam adalah agama yang selain bersifat syumuliyah (sempurna) juga harakiyah (dinamis), disebut sempurna karena Islam merupakan agama penyempurna dari agama-agama sebelumnya dan syari'atnya mengatur seluruh aspek kehidupan, baik yang bersifat aqidah maupun muamalah. Dalam kaidah muamalah, Islam mengatur segala bentuk perilaku manusia dalam berhubungan dengan sesamanya untuk memenuhi kebutuhan hidupnya di dunia, termasuk di dalam kaidah Islam yang mengatur tentang pasar dan mekanismenya.

Pasar adalah tempat dimana antara penjual dan pembeli bertemu dan melakukan transaksi jual beli barang atau jasa. Pentingnya pasar dalam Islam tidak terlepas dari fungsi pasar sebagai wadah bagi berlangsungnya kegiatan jual beli, aturan, norma yang terkait dengan masalah pasar. Dengan fungsi di atas pasar jadi rentan dengan sejumlah kecurangan dan juga perbuatan ketidakadilan yang mendzalimi pihak lain, maka pasar tidak terlepas dengan sejumlah aturan syariat yang terkait dengan pembentukan harga dan terjadinya transaksi di pasar. Dalam istilah lain dapat disebut sebagai mekanisme pasar menurut Islam.

Secara umum saat ini banyak terjadi kelangkaan dan mahalnya harga pangan dunia yang terasa berdampak bagi masyarakat luas terutama bagi masyarakat miskin. Akibatnya inflasi akan menggerus ekonomi dan telah menjadi keluhan 
banyak negara saat ini. Dalam konteks ekonomi dalam negeri juga tidak akan sunyi dari imbasnya, misalnya terjadi kenaikan harga bahan pokok dan pasar menjadi tidak menentu.

\section{B. Rumusan Masalah}

Berdasarkan latar belakang yang telah penulis uraikan, maka pokok masalah yang diangkat dalam makalah ini adalah sebagai berikut :

1. Bagaimana pasar di masa Rasulullah ?

2. Bagaimana pandangan ekonom muslim ?

3. Bagaimana peranan pemerintah dalam mengawasi pasar?

\section{Tujuan}

Sejalan dengan rumusan masalah yang telah dituangkan, maka tujuan penulisan ini adalah sebagai berikut:

1. Untuk mengetahui dan menambah wawasan mengenai pasar di masa Rasulullah.

2. Untuk mengetahui dan menganalisis pandangan para ekonom-ekonom muslim.

3. Untuk mengetahui peranan pemerintah dalam mengawasi pasar. 


\section{BAB II}

\section{PEMBAHASAN}

\section{A. Pasar Di Masa Rasulullah}

Pasar luar negeri yang dikunjungi Rasulullah Saw ketika masih berusia 12 tahun terletak di Bushra atau Bashrah, sebuah negara yang bernama Syam. Perjalanan ini dilakukan pada 582 Masehi mengikuti pamannya Abu Thalib. ${ }^{1}$ Negeri Syam adalah negeri tetangga yang terpenting bagi daerah Semenanjung Arabia Negeri ini terkenal subur dan kaya raya sehingga selalu menjadi tujuan utama bagi penduduk Semenanjung Arabia yang ingin mencari penghidupan baru. Di negeri ini mereka menetap sambil menggembalakan ternak di padang rumput yang ada atau menjalin hubungan bisnis dengan penduduk setempat. Hubungan antara Syam dan Jazirah Arab tidak pernah putus dari waktu ke waktu yang secara umum selalu fokus dalam bidang perdagangan, juga ekspor impor untuk berbagai bahan makanan dan hasil industri pokok masyarakat. Jalur Hijaz Syam adalah jalur terpenting yang dipadati oleh kafilah-kafilah dagang yang bolak balik membawa barang dagangan mereka dari negeri satu ke negeri lainnya.

Perlakuan berbeda yang dilakukan Bahira terhadap rombongan Quraisy saat itu. "Demi Allah wahai Bahira, kami melihat engkau bersikap lain hari ini Pada waktu

${ }^{1}$ Yenni Samri Juliati Nasution, "Mekanisme Pasar Dalam Perspektif Ekonomi Islam", AtTawassuth, 3.1 (2018): h. 16. 
waktu sebelumnya, engkau tidak pernah menjamu kami, padahal kami sering melewati tempatmu. Apa yang terjadi denganmu hari ini? Bahira menjawab, "Apa yang kau katakan benar. Kalian pada saat ini adalah tamuku dan aku ingin memuliakan kalian dengan menyediakan jamuan. Aku berharap agar kalian semua dapat menghadirinya."

Beberapa saat kemudian, semua anggota rombongan sudah berkumpul di pertapaan Bahira, kecuali Rasulullah Saw yang tetap tinggal di tempatnya sehingga tidak ikut menghadiri jamuan karena masih kanak-kanak. Bahira mengamati orangorang yang hadir dan berkata, "Wahai orang-orang Quraisy saya tidak ingin ada seorang pun di antara kalian yang tidak menghadiri jamuanku ini Rombongan Quraisy tersebut kemudian menjawab, "Tidak seorang pun di antara kami yang tidak hadir di sini, kecuali seorang anak kecil la adalah anggota rombongan yang paling muda sehingga harus tinggal di tempat." Bahira berkata, berbuat begitu, panggil dia untuk hadir bersama-sama kalian di tempatku Salah seorang anggota kafilah Quraisy itu kemudian berkata, "Demi Lata Jangan dan Uzza, tidak akan dicela kita karena anak Abdullah bin Abdul Muthallib ikut ini. duduk dan makan bersama kita."

Orang itu kemudian pergi menemui Muhammad dan membawanya ke tempat perjamuan tersebut. Pada saat Muhammad menikmati jamuan, Bahira memperhatikan dengan seksama. Bahira juga menatap tubuh beliau dengan terus tatapan menyelidik seakan-akan tengah mencari sesuatu pada tubuh beliau. Pada saat semua yang hadir telah selesai makan dan mulai meninggalkan tempat 
duduknya, Bahira lalu menghampiri Nabi Muhammad Saw. dan berkata, "Wahai anak kecil, demi Lata dan Uzza, aku ingin engkau memberitahukan kepadaku apa yang akan aku tanyakan kepadamu." Bahira menggunakan nama Lata dan Uzza. Demi Allah, aku sama sekali tidak pernah membenci sesuatu demi keduanya."

Menyimak percakapan tersebut betapa jelas bahwa pasar memegang peranan dalam perekonomian masyarakat muslim pada masa Rasulullah Saw. dan Khulafaurrasyidin. Bahkan Muhammad Saw. sendiri pada awalnya seorang penting pebisnis, demikian pula Khulafaurrasyidin dan kebanyakan sahabat. Pada saat awal perkembangan Islam di Mekah Rasulullah Saw. dan masyarakat Muslim mendapat gangguan dan teror yang berat dari masyarakat kafir Mekah sehingga perjuangan dan dakwah menjadi prioritas. Ketika masyarakat muslim telah berhijrah ke Madinah, peran Rasulullah Saw, bergeser menjadi pengawas pasar atau Al muhtasib.

Ketika itu mekanisme pasar sangat dihargai. Beliau menolak untuk membuat kebijakan penetapan harga manakala tingkat harga di Madinah tiba-tiba naik saat itu. Sepanjang kenaikan terjadi karena kekuatan permintaan dan penawaran yang murni atau tidak dibarengi dengan dorongan-dorongan monopolistik dan monopsonistik, maka tidak ada alasan untuk tidak menghormati harga pasar. Dalam suatu hadis dijelaskan tentang pasar adalah hukum alam (sunnatullah) yang harus dijunjung tinggi. Tak seorang pun secara individual dapat memengaruhi pasar.

Pelanggaran terhadap harga pasar, misalnya penetapan harga dengan cara dan alasan yang tidak tepat sebagai suatu ketidakadilan (injustice) yang akan dituntut 
pertanggungjawabannya di hadapan Allah dan begitu pun sebaliknya. Penghargaan Islam terhadap mekanisme pasar berdasarkan pada ketentuan Allah Swt. bahwa perniagaan harus dilakukan secara baik dengan rasa suka sama suka dan nilai moralitas mutlak yang harus ditegakkan. Secara khusus nilai moralitas yang mendapat perhatian penting dalam pasar adalah persaingan yang sehat, kejujuran, keterbukaan, dan keadilan.

Konsep mekanisme pasar dalam Islam dapat dirujuk kepada hadis Rasulullah Saw yang disampaikan oleh Anas ra. sehubungan dengan kenaikan harga harga barang di kota Madinah. Dengan hadis ini terlihat dengan jelas bahwa Islam jauh lebih dahulu (lebih 1160 tahun) mengajarkan konsep mekanisme pasar. Rasulullah Saw dalam hadis tidak mau menentukan harga dan menunjukkan ketentuan harga yang diserahkan kepada mekanisme pasar yang alamiah impersonal. Rasulullah menolak tawaran dan mengatakan bahwa harga di pasar tidak boleh ditetapkan karena Allah yang menentukannya. Sungguh menakjubkan teori Nabi tentang harga dan pasar. Ucapan Nabi Saw itu mengandung pengertian bahwa harga pasar itu sesuai dengan kehendak Allah yang sunnatullah atau mengikuti hukum permintaan dan penawaran.

Menurut pakar ekonomi Islam kontemporer, teori ini diadopsi oleh Bapak Ekonomi Barat, Adam Smith dengan nama teori bernama invisible hands. ${ }^{2}$ Menurut

2 Akhmad Mujahidin, Ekonomi Islam Sejarah, Konsep, Instrumen, Negara Dan Pasar (Cet. I; Jakarta: Rajawali Pers, 2013), h. 68. 
teori ini, pasar akan diatur oleh tangan-tangan tidak kelihatan (invisible hands) Bukankah teori ini lebih tepat dikatakan God Hands (tangan-tangan Allah)? Pasar, negara, individu dan masyarakat selalu menjadi diskursus hangat dalam ilmu ekonomi. Menurut ekonomi kapitalis (klasik), pasar memainkan peranan yang sangat penting dalam sistem perekonomian.

Ekonomi kapitalis menghendaki pasar bebas untuk menyelesaikan perma salahan ekonomi mulai dari produksi, konsumsi, dan distribusi. ${ }^{3}$ Semboyan kapitalis adalah lassez fairect (biarkan ia berbuat dan biarkan ia berjalan, dunia akan mengurus diri sendiri). Maksudnya adalah biarkan saja perekonomian berjalan dengan wajar tanpa intervensi pemerintah, nanti akan ada tangan tak terlihat (invisible hands) yang akan membawa perekonomian tersebut ke arah semengaruhi harga equilibrium. Jika banyak campur tangan pemerintah, maka pasar akan mengalami distorsi yang akan membawa perekonomian pada ketidakefisienan (inefisiency) hingga diperlukan dan ketidakseimbangan.

Menurut konsep tersebut, pasar yang paling baik adalah persaingan bebas (free competition), sedangkan harga dibentuk oleh kaidah permintaan dan penawaran. Prinsip pasar bebas akan menghasilkan equilibrium dalam masya rakat yang akan menghasilkan upah (wage) yang adil, harga barang (price) yang stabil, dan kondisi tingkat pengangguran yang rendah (full employment). Untuk itu peranan negara dalam ekonomi harus diminimalisasi sebab negara yang ikut campur bermain

3 Alang, Agung Zulkarnaian, ” Mekanisme Pasar Dalam Perspektif Ekonomi Islam”, Institution And Sharia Finance, 1.2 (2018): h. 40. 
dalam ekonomi hanya akan menyingkirkan sektor swasta sehingga mengganggu equilibrium pasar. Dalam paradigma kapitalisme, mekanisme pasar diyakini akan menghasilkan suatu keputusan yang adil dan bijaksana dalam berbagai kepentingan yang bertemu di pasar. Para pendukung paradigma pasar bebas telah melakukan berbagai upaya akademis untuk meya kinkan bahwa pasara adalah sebuah sistem yang mandiri (self regulating).

\section{B. Pandangan Ekonom Muslim}

Dalam konsep ekonomi Islam penentuan harga dilakukan oleh kekuatankekuatan pasar, yaitu kekuatan permintaan dan kekuatan penawaran. ${ }^{4}$ Dalam konsep Islam, pertemuan permintaan dengan penawaran tersebut haruslah terjadi secara rela sama rela, tidak ada pihak yang merasa terpaksa untuk melakukan transaksi pada tingkat harga tersebut.

Keadaan rela sama rela merupakan kebalikan dari keadaan aniaya, yaitu keadaan di mana salah satu pihak senang di atas kesedihan pihak lain. Dalam hal harga, para ahli fiqih merumuskannya sebagai the price of the equivalent.27 Konsep the price of the equivalent ini mempunyai implikasi penting dalam ilmu ekonomi, yaitu keadaan pasar yang kompetitif.

${ }^{4}$ Adiwarman Azwar Karim, Ekonomi Mikro Islam (Cet. III; Jakarta: Rajawali Pers, 2014), h. 156 . 


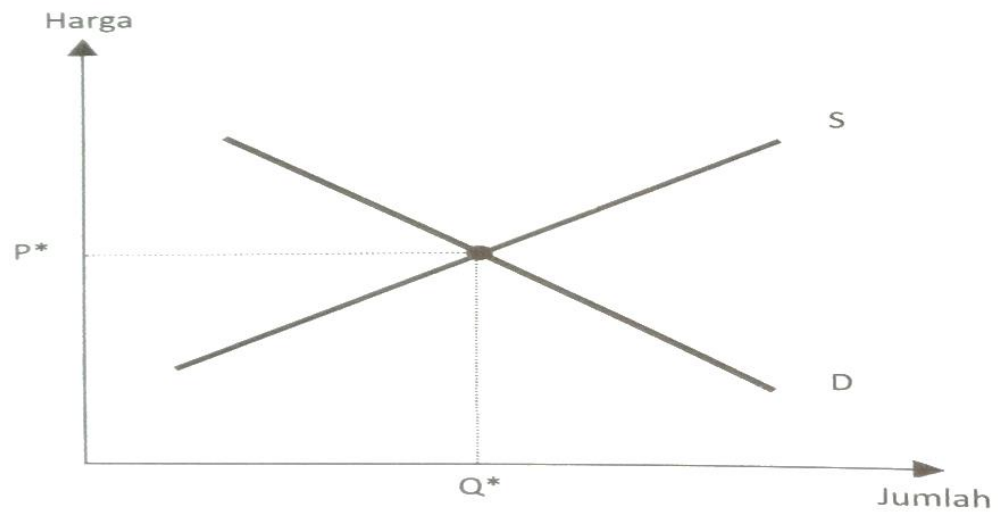

Dalam konsep Islam, monopoly, duopoly, oligopoly dalam artian hanya ada satu penjual, dua penjual, atau beberapa penjual tidak dilarang keberadaannya, selama mereka tidak mengambil keuntungan di atas keuntungan normal. Ini merupakan konsekuensi dari konsep the price of the equivalent. Produsen yang beroperasi dengan positif profit akan mengudang produsen lain untuk masuk ke dalam bisnis tersebut, sehingga kurva supply bergeser ke kanan, jumlah output yang ditawarkan bertambah, dan harga akan turun. Produsen baru akan terus memasuki bisnis tersebut sampai dengan harga turun sedemikian sehingga economic profit nihil. Pada keadaan ini produsen yang telah ada di pasar tidak mempunyai insentif untuk keluar dari pasar, dan produsen yang belum masuk ke pasar tidak mempunyai insentif untuk masuk ke pasar.

Islam mengatur agar persaingan di pasar dilakukan dengan adil. Setiap bentuk yang dapat menimbulkan ketidakadilan dilarang..$^{5}$

1. Talaqqi rukban dilarang karena pedagang yang menyongsong di pinggir kota mendapat keuntungan dari ketidaktahuan penjual dari kampung akan

\footnotetext{
${ }^{5}$ Muhammad, Ekonomi Mikro Islam (Cet. I; Yogyakarta: BPFE, 2016), h. 190.
} 
harga yang berlaku di kota. Mencegah masuknya pedagang desa ke kota ini (entry barrier) akani menimbulkan pasar yang tidak kompetitif.

2. Mengurangi timbangan dilarang karena barang dijual dengan harga yang sama untuk jumlah yang lebih sedikit.

3. Menyembunyikan barang cacat dilarang karena penjual mendapatkan harga yang baik untuk kualitas yang buruk.

4. Menukar kurma kering dengan kurma basah dilarang, karena takaran kurma basah ketika kering bisa jadi tidak sama dengan kurma kering yang ditukar.

5. Menukar satu takar kurma kualitas bagus dengan dua takar kurma kualitas sedang dilarang karena setiap kualitas kurma mempunyai harga pasarnya. Rasulullah menyuruh menjual kurma yang satu, kemudian membeli kurma yang lain dengan uang.

6. Transaksi Najasy dilarang karena si penjual menyuruh orang lain memuji barang nya atau menawar dengan harga tinggi agar orang lain tertarik.

7. Ikhtikar dilarang, yaitu mengambil keuntungan di atas keuntungan normal dengan menjual lebih sedikit barang untuk harga yang lebih tinggi.

8. Ghaban faa-hisy (besar) dilarang yaitu menjual di atas harga pasar.

Kajian tentang mekanisme pasar telah banyak di bahas oleh para ulama klasik jauh sebelum para ekonom Barat membahasnya. Ada beberapa ulama klasik yang 
pernah membahas tentang ekonomi Islam dalam hal mekanisme pasar secara empiric, di antaranya : 6

\section{Abu Yusuf}

Ulama yang pertama kali membahas mekanisme pasar secara empirik adalah Abu Yusuf, yang hidup di awal abad kedua Hijriyah (731-798). Dia telah membahas tentang hukum supply and demand dalam perekonomian. Pemahaman yang berkembang ketika itu mengatakan bahwa bila tersedia sedikit barang, maka harga akan mahal dan bila tersedia banyak barang, maka harga akan murah.

Menurut Abu Yusuf semakin Sedikit barang, harga semakin naik. Dengan kata lain, pemahaman pada zaman Abu Yusuf tentang hubungan harga dan kuantitas hanya memperhatikan kurva permintaan. Ia membantah pemahaman seperti ini, karena pada kenyataannya persediaan barang sedikit tidak selalu dikuti dengan kenaikan harga, dan sebaliknya persediaan barang melimpah belum tentu membuat harga akan murah. " Kadang-kadang makanan berlimpah, tetapi tetap mahal, dan kadang-kadang makanan sangat sedikit tetapi murah". Adalah benar bahwa tingkat harga tidak hanya bergantung pada penawaran semata, namun kekuatan permintaan juga penting. Oleh karena itu kenaikan atau penurunan tingkat harga tidak selalu harus berhubungan dengan kenaikan dan penurunan produksi saja. Dalam mempertahankan pendapat ini

\footnotetext{
${ }^{6}$ Abdul Ghofur, Pengantar Ekonomi Syariah Konsep Dasar, Paradigma, Pengembangan Ekonomi Syariah (Cet. I; Kaliwungu: Rajawali Pers, 2017), h. 86.
} 
Abu Yusuf mengatakan bahwa ada beberapa variabel dan alasan lainnya yang bisa mempengaruhi, tetapi ia tidak menjelaskan secara detail, mungkin karena alasan-alasan penyingkatan.

Mungkin variabel itu adalah pergeseran dalam permintaan atau jumlah uang yang beredar di suatu negara atau penimbunan dan penahanan barang. Dalam konteks ini Abu Yusuf mengemukakan bahwa tidak ada batasan tertentu tentang rendah dan mahalnya harga barang. Hal tersebut ada yang mengaturnya. Murah bukan karena melimpahnya makanan, demikian juga mahal bukan disebabkan kelangkaan makanan. Murah dan mahal adalah ketentuan Allah.

Dalam hal ini Muhammad Nejatullah Ash-Shiddiqi berkomentar, Telaahan Abu Yusuf tentang mekanisme pasar harus diterima sebagai pernyataan hasil pengamatannya saat itu, yakni keberadaan yang bersamaan antara melimpahnya barang dan tingginya harga serta kelangkaan barang dan harga murah. Dengan demikian meskipun Abu Yusuf tidak mengulas secara rinci tentang mekanisme pasar (yakni tentang variabel-variabel lain), Namun pernyataannya tidak menyangkal pengaruh supply dan demand dalam penentuan harga.

\section{Ibnu Taimiyah}

Masyarakat pada masa lbn Taimiyah beranggapan bahwa peningkatan harga merupakan akibat dari ketidakadilan dan tindakan melanggar hukum dari pihak penjual atau mungkin sebagai akibat manipulasi pasar. Anggapan ini 
dibantah oleh Ibn Taimiyah Dengan tegas ia mengatakan bahwa harga ditentukan oleh kekuatan permintan dan penawaran

la menyatakan bahwa naik dan turunnya harga tidak selalu disebabkan oleh tindakan tidak adil dari sebagian orang yang terlibat transaksi. Bisa jadi penyebabnya adalah penawaran yang menurun akibat inefisiensi produksi, penurunan jumlah impor barang-barang yang diminta atau juga tekanan pasar Karena itu, jika permintaan terhadap barang meningkat, sedangkan penawaran menurun, harga barang tersebut akan naik. Begitu pula sebaliknya. Kelangkaan dan melimpahnya barang mungkin disebabkan oleh tindakan yang adil atau mungkin juga tindakan yang tidak adil.

Menurut Ibn Taimiyah, penawaran bisa datang dari produksi domestik dan impor. Perubahan dalam penawaran digambarkan sebagai peningkatan atau penurunan dalam jumlah barang yang ditawarkan, sedangkan permintaan sangat ditentukan oleh selera dan pendapatan Besar kecilnya kenaikan harga bergantung pada besarnya perubahan penawaran dan atau permintaan Bila seluruh transaksi sudah sesuai aruran, kenaikan harga yang terjadi merupakan kehendak Allah. Hal tersebut menunjukkan sifat pasar yang impersonal.. Dibedakan pula dua faktor penyebab pergeseran kurva penawaran dan permintaan, yaitu tekanan pasar yang otomatis dan perbuatan melanggar hukum dari penjual, misalnya penimbunan. 


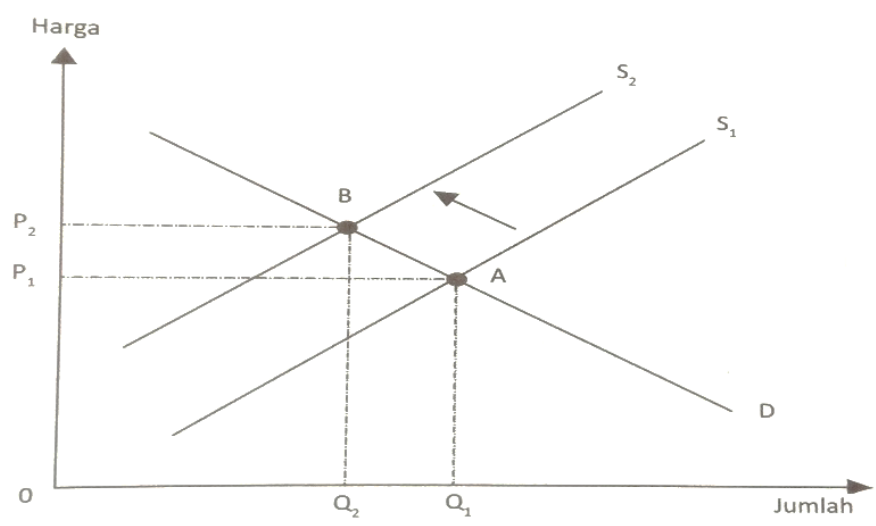

Awalnya titik ekuilibrium terjadi pada titik A dengan harga $\mathrm{P}$, dan jumlah Q Namun, karena terjadi inefisiensi produksi, maka terjadi kenaikan biaya produksi yang harus ditanggung oleh perusahaan Kenaikan biaya produksi ini menyebabkan pergeseran kurva supply dari S, menjadi S,. Karena pergeseran ini, maka tercipta titik ekuilibrium baru pada titik B. Pada titik B ini, terjadi penurunan kuantitas yang ditawarkan dari Q, menjadi Q,, dan pada saat yang sama terjadi kenaikan harga dari $\mathrm{P}$, menjadi P.

Bila seluruh transaksi sudah sesuai aturan, kenaikan harga yang terjadi merupakan kehendak Allah. Hal tersebut yang impersonal. Ibn Taimiyah juga membedakan dua faktor penyebab pergeseran kurva penawaran dan permintaan, yaitu tekanan pasar yang otomatis dan perbuatan melanggar hukum dari penjual, misalnya penimbunan

Adapun faktor lain yang memengaruhi permintaan dan penawaran antara lain adalah intensitas dan besarnya permintaan, kelangkaan atau melimpahnya barang, kondisi kepercayaan, serta diskonto dari pembayaran tunai Permintaan terhadap barang acapkali berubah. Perubahan tersebut bergantung pada jumlah penawaran, jumlah orang yang menginginkannya,

kuat-lemahnya dan besar kecilnya kebutuhan terhadap barang tersebut. Bila penafsiran ini benar, Ibn Taimiyah telah mengasosiasikan harga tinggi 
dengan intensitas kebutuhan sebagaimana kepentingan relatif barang terhadap total kebutuhan pembeli. Bila kebutuhan kuat dan besar, harga akan naik. Demikian pula sebaliknya.

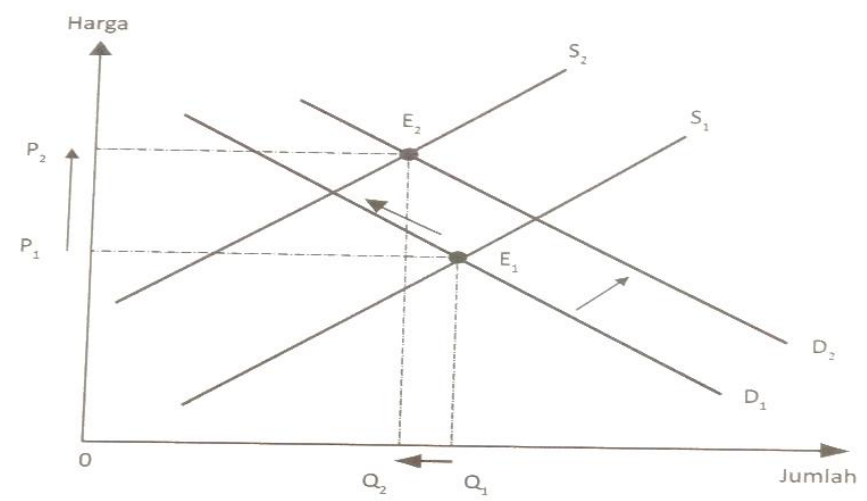

Harga juga dipengaruhi oleh tingkat kepercayaan terhadap orang-orang yang terlibat dalam transaksi. Bila seseorang cukup mampu dan terpercaya dalam membayar kredit, penjual akan senang melakukan transaksi dengan orang tersebut. Namun, apabila kredibilitas seseorang dalam masalah kredit telah diragukan, penjual akan ragu untuk melakukan transaksi dengan orang tersebut dan cenderung memasang harga tinggi (dalam peristilahan ekonomi modern, hal ini diebut sebagai risk premium) Demikian juga apabila menggunakan kontrak

Pada tempat yang lain Ibn Taimiyah mengemukakan relevansi antara kredit terhadap penjualan. Karena itu kita dapat berkesimpulan bahwa transaksi kredit merupakan hal yang wajar pada saat itu. Ketika menetapkan harga, para penjual harus memerhatikan ketidakpastian pembayaran pada masa yang akan datang. la juga menengarai kemungkinan penjual menawarkan diskon untuk transaksi 
tunai. Dengan demikian, Ibn Taimiyah bukan saja menyadari kekuatan penawaran dan permintaan, melainkan juga menyadari insentif, disinsentif, ketidakpastian, dan risiko yang terlibat dalam transaksi pasar

Menarik untuk dicatat bahwa tampaknya Ibn Taimiyah mendukung kebebasan untuk keluar masuk pasar la misalnya mengatakan bahwa memaksa orang agar menjual berbagai benda yang tidak diharuskan untuk menjualnya atau melarang mereka menjual barang-barang yang diperbolehkan untuk dijual, merupakan suatu hal yang tidak adil dan karenanya melanggar hukum.”

Lebih jauh, ia mengkritik adanya kolusi antara pembeli dan penjual." Ia menyokong homogenitas dan standarisasi produk dan melarang pemalsuan produk serta penipuan pengemasan produk untuk dijual.

Ibn Taimiyah menentang peraturan yang berlebihan ketika kekuatan pasar secara bebas bekerja untuk menentukan harga yang kompetitif. Dengan tetap memerhatikan pasar yang tidak sempurna, ia merekomendasikan bahwa bila penjual melakukan penimbunan dan menjual pada harga yang lebih tinggi dibandingkan dengan harga normal padahal orang-orang membutuhkan barang-barang ini, maka para penjual diharuskan untuk menjualnya pada tingkat harga ekuivalen. Secara kebetulan, konsep ini bersamaan artinya dengan apa yang disebut sebagai harga yang adil. Selanjutnya, bila ada elemen-elemen monopoli (khususnya dalam pasar bahan makanan dan kebutuhan pokok lainnya), pemerintah harus turun tangan melarang kekuatan monopoli." 


\section{Ibnu Khaldun}

Selain, Abu Yusuf, Ibnu Taymiyah dan al-Ghazali, intelektual muslim yang juga membahas teori harga adalah Ibnu Khaldun. Di dalam Al Muqaddimah, ia menulis secara khusus bab yang berjudul, "Harga-harga di Kota”. Ia membagi jenis barang kepada dua macam, pertama, barang kebutuhan pokok, kedua barang mewah. Menurutnya, bila suatu kota berkembang dan populasinya bertambah, maka pengadaan barang-barang kebutuhan pokok mendapat prioritas, sehingga penawaran meningkat dan akibatnya harga menjadi turun. Sedangkan untuk barang-barang mewah, permintaannya akan meningkat, sejalan dengan perkembangan kota dan berubahnya gaya hidup. Akibatnya, harga barang mewah menjadi naik. Selanjutnya Ibnu Khaldun mengemukakan mekanisme penawaran dan permintan dalam menentukan harga keseimbangan. Pada sisi permintaan demand, ia memaparkan pengaruh persaingan diantara konsumen untuk mendapatkan barang. Sedngkan pada sisi penawaran (supply) ia menjelaskan pula pengaruh meningkatnyaa biaya produksi karena pajak dan pungutan-pungutan lain dikota tersebut.Pengaruh naik turunnya penawaran terhadap harga. Menurutnya, ketika barang-barang yang tersedia sedikit, maka harga-harga akan naik. Namun, bila jarak antara kota dekat dan amam, maka akan banyak barang yang diimpor sehingga ketersediaan barang akan melimpah dan harga-harga akan turun Paparan itu menunjukkan bahwa Ibnu Khaldun telah mengidentifikasi kekuatan permintaan dan penawaran sebagai penentu keseimbangan harga. Masih berkaitan dengan 
teori supply and demand, Ibnu Khaldun menjelaskan secara lebih detail. Menurutnya keuntungan yang wajar akan mendorong tumbuhnya perdagangan, sedangkan keuntungan yang sangat rendah, akan membuat lesu perdagangan, karena pedagang kehilangan motivasi. Sebaliknya bila pedagang mengambil keuntungan sangat tinggi, juga akan membuat lesu perdagangan, karena lemahnya permintaan (demand) konsumen. Apabila dibandingkan dengan Ibnu Taymiyah yang tidak menggunakan istilah persaingan, Ibnu Khaldun menjelaskan secara eksplisit elemen-elemen persaingan. Bahkan ia juga menjelaskan secara eksplisit jenis-jenis biaya yang membentuk kurva penawaran, sedangkan Ibnu Taymiyah menjelaskannya secara implisit saja. Berdasarkan kajian para ulama klasik tentang mekanisme pasar, maka Muhammad Najatullah Shiddiqi, dalam buku The Economic Entreprise in Islam, menulis bahwa "Sistem pasar di bawah pengaruh semangat Islam berdasarkan dua asumsi. Asumsi itu adalah rasionalitas ekonomi dan persaingan sempurna. Berdasarkan asumsi ini, sistem pasar di bawah pengaruh semangat Islam dapat dianggap sempurna. Sistem ini menggambarkan keselarasan antar kepentingan para konsumen.” Dalam hal ini Muhammad Nejatullah ash Shiddiqi menyimpulkan bahwa ciri-ciri penting pendekatan Islam dalam hal mekanisme pasar adalah:

a) Penyelesaian masalah ekonomi yang asasi (konsumsi, produksi, dan distribusi), dikenal sebagai tujuan mekanisme pasar. 
b) Dengan berpedoman pada ajaran Islam, para konsumen diharapkan bertingkah laku sesuai dengan mekanisme pasar, sehingga dapat mencapai tujuan yang dinyatakan di atas.

c) Dan yang Jika perlu, campur tangan negara sangat urgen diberlakukan untuk normalisasi dan memperbaiki mekanisme pasar yang rusak. Sebab negara adalah penjamin terwujudnya mekanisme pasar yang normal.

Selanjutnya menurut Islam negara memiliki hak untuk ikut campur (intervensi) dalam kegiatan ekonomi yang dilakukan oleh individu-individu, baik untuk mengawasi kegiatan ini maupun untuk mengatur atau melaksanakan beberapa macam kegiatan ekonomi yang tidak mampu dilaksanakan oleh individu-individu. Keterlibatan negara dalam kegiatan ekonomi pada permulaan Islam sangat kurang, karena masih sederhananya kegiatan ekonomi yang ketika itu, selain itu disebabkan pula oleh daya kontrol spiritual dan kemantapan jiwa kaum muslimin pada masa-masa permulaan yang membuat mereka mematuhi secara langsung perintah-perintah syariat dan sangat berhatihati menjaga keselamatan mereka dari penipuan dan kesalahan. Semua ini mengurangi kesempatan negara untuk ikut campur (intervensi) dalam kegiatan ekonomi. Seiring dengan kemajuan zaman, kegiatan ekonomi pun mengalami perkembangan yang cukup signifikan. Namun perkembangan yang ada cenderung menampakkan komleksitas dan penyimpangan-penyimpangan etika dalam kegiatan ekonomi. Atas dasar itulah, maka Ibnu Taimiyah, memandang 
perlu keterlibatan (intervensi) negara dalam aktifitas ekonomi dalam rangka melindungi hak-hak rakyat/masyarakat luas dari ancaman kezaliman para pelaku bisnis yang ada, dan untuk kepentingn manfaat yang lebih besar. Dalam kaitan ini, maka intervensi negara dalam kegiatan ekonomi bertujuan menghilangkan kemiskinan.

\section{Al Ghazali}

Kalau Ibnu Taymiyah, yang hidup lima ratus tahun sebelum Adam Smith, sudah membicarakan teori harga, ternyata al-Ghazali (1058-1111) yang hidup tujuh ratus tahun sebelum Smith, juga telah membicarakan mekanisme pasar yang mencakup teori harga dan konsep supply and demand. Al-Ghazali dalam Ihya 'Ulumuddin, juga telah membahas secara detail peranan aktivitas perdagangan dan timbulnya pasar yang harganya bergerak sesuai dengan kekuatan penawaran dan permintaan. Menurutnya, pasar merupakan bagian dari keteraturan alami. Walaupun al-Ghazali tidak menjelaskan permintaan dan penawaran dalam terminologi modern, beberapa paragraf dari tulisannya jelas menunjukkan bentuk kurva penawaran dan permintaan. Untuk kurva penawaran "yang naik dari kiri bawah ke kanan atas", dinyatakan dalam kalimat, "Jika petani tidak mendapatkan pembeli barangnya, maka ia akan menjualnya pada harga yang lebih murah.

Pemikiran al-Ghazali tentang hukum supply and demand, untuk konteks zamannya cukup maju dan mengejutkan dan tampaknya dia paham betul 
tentang konsep elastisitas permintaan. Ia menegaskan, "Mengurangi margin keuntungan dengan menjual pada harga yang lebih murah, akan meningkatkan volume penjualan dan ini pada gilirannya akan meningkatkan keuntungan. Bahkan ia telah pula mengidentifikasikan produk makanan sebagai komoditas dengan kurva permintaan yang inelastis. Komentarnya, "karena makanan adalah kebutuhan pokok, maka perdagangan makanan harus seminimal mungkin didorong agar tidak semata dalam mencari keuntungan. Dalam bisnis makanan pokok harus dihindari eksploitasi melalui pengenaan harga yang tinggi dan keuntungan yang besar. Keuntungan semacam ini seharusnya dicari dari barang-barang yang bukan merupakan kebutuhan pokok.

Imam al-Ghazali, sebagaimana ilmuwan muslim lainnya dalam membicarakan harga selalu mengkaitkannya dengaan keuntungan. Dia belum mengkaitkan harga barang dengan pendapatan dan biaya-biaya. Bagi alGhazali, keuntungan (ribh), merupakan kompensasi dari kesulitan perjalanan, resiko bisnis dan ancaman keselamatan si pedagang. Meskipun al-Ghazali menyebut keuntungan dalam tulisannya, tetapi kita bisa paham, bahwa yang dimaksudkannya adalah harga. Artinya, harga bisa dipengaruhi oleh keamanan perjalanan, resiko, dsb. Perjalanan yang aman akan mendorong masuknya barang impor dan menimbulkan peningkatan penawaran, akibatnya harga menjadi turun, demikian pula sebaliknya.

\section{Peranan Pemerintah Dalam Mengawasi Pasar}

Peranan pemerintah sangat penting untuk lebih menjamin berjalannya 
mekanisme pasar secara sempurna. Rasulullah SAW sendiri telah menjalankan fungsi sebagai pengawas pasar atau al-Hisbah, yang kemudian banyak dijadikan acuan untuk peran negara terhadap pasar. Rasulullah SAW sering melakukan inspeksi ke pasar untuk mengecek harga dan mekanisme pasar. ${ }^{7}$

Seringkali dalam inspeksinya, beliau banyak menemukan praktik bisnis yang tidak jujur sehingga beliau menegurnya. Rasulullah SAW juga banyak memberikan pendapat, perintah maupun larangan demi terciptanya pasar yang Islami. Semua ini mengindikasikan dengan jelas bahwa al-Hisbah telah ada sejak masa Rasulullah SAW, meskipun nama al-Hisbah baru datang di masa kemudian. Sementara, tujuan al-Hisbah menurut Ibnu Taimiyah adalah untuk memerintahkan apa yang disebut sebagai kebaikan dan mencegah apa yang secara umum disebut sebagai keburukan di dalam wilayah yang menjadi kewenangan pemerintah untuk mengaturnya, mengadili dalam wilayah umum khusus lainnya, yang tak bisa dijangkau oleh institusi biasa. Jadi, al-Hisbah adalah semacam polisi khusus ekonomi. Bahkan lembaga ini merupakan suatu agen independen sehingga terlepas dari kepentingan kelompok tertentu atau pemerintah itu sendiri. Namun, dengan melihat fungsi al-Hisbah yang luas dan strategis ini, adanya suatu agen independen, tampak al-Hisbah akan melekat pada fungsi pemerintah secara keseluruhan, di mana dalam teknis

${ }^{7}$ Veithzal Rivai Zainal, Nurul Huda, Ratna Ekawati, Sri Vandayuli Riorini, Ekonomi Mikro Islam (Cet. I; Jakarta: Bumi Aksasra, 2018), h. 97. 
operasionalnya akan dijalankan oleh kementerian, departemen, dinas atau lembaga lain yang terkait.

Dalam pandangan Islam, peran pemerintah didasari oleh beberapa argumentasi, yaitu: ${ }^{8}$

1. Derivasi dari konsep kekhalifahan.

2. Konsekuensi adanya kewajiban-kewajiban kolektif.

3. Adanya kegagalan pasar dalam merealisasikan falah.

Adapun yang mungkin menjadi kegagalan masyarakat dalam menjalankan fardh al-kifayah ini disebabkan beberapa hal, yaitu:

1. Asimetri dan kekurangan informasi.

2. Pelanggaran moral.

3. Kekurangan sumber daya atau kesulitan teknis.

Kegagalan pasar juga merupakan latar belakang perlunya pemerintah untuk berperan dalam perekonomian. Kegagalan pasar adalah ketidakmampuan dari suatu perekonomian pasar untuk berfungsi secara efisien dan menimbulkan keteguhan dan pertumbuhan ekonomi. Kegagalan pasar atau market failure terjadi ketika mekanisme harga gagal untuk memperhitungkan semua biaya dan manfaat yang diperlukan, baik untuk menyediakan dan mengkonsumsinya. Pasar akan gagal dengan tidak menyediakan jumlah yang optimal secara baik dari asfek sosial.

${ }^{8}$ Ika Yunia Fauziah, Abdul Kadir Riyadi, Prinsip Dasar Ekonomi Islam Prespektif Maqashid al-syariah (Cet. I; Sidoarjo: Kencana, 2013), h. 223. 
Pemerintah memiliki tugas penting dalam mewujudkan tujuan ekonomi Islam secara keseluruhan. Sebagaimana telah diketahui, tujuan ekonomi Islam adalah mencapai falah yang direalisasikan melalui optimasi mahslahah. Oleh karena itu, sebagai pengemban amanah dari Allah SWT dan masyarakat, maka secara umum tujuan peran pemerintah adalah menciptakan ke-mashlahat-an bagi seluruh masyarakat.

Menurut al-Mawardi, tugas dari pemerintah adalah untuk melanjutkan fungsi-fungsi kenabian dalam menjaga agama Islam dan mengatur urusanurusan duniawi.

Pemerintah mempunyai peranan penting dalam mewujudkan pasar yang Islami. Intervensi pemerintah dalam pasar bukan hanya bersifat temporer dan minor, tetapi ia akan mengambil peranan yang besar dan penting. Peran pemerintah dalam pasar ini secara garis besar dapat diklasifikasikan menjadi dua bagian, yaitu: ${ }^{9}$

1. peran yang berkaitan dengan implementasi nilai dan moral Islam

2. Peran yang berkaitan dengan teknis operasional mekanisme pasar.adapun yang menjadi contoh peran pemerintah yang berkaitan dengan implementasi moralitas Islam adalah sebagai berikut ;

- Memastikan dan menjaga implementasi nilai dan moral

${ }^{9}$ Rasti Ardiana, "Peran Pemerintah Dalam Mengawasi”, Ekonomi Syariah, 2.1 (2020): h. 17. 
- Islam secara keseluruhan Memastikan dan menjaga agar pasar hanya memperjualkan belikan barang dan jasa yang halal.

- Melembagakan nilai-nilai persaingan yang sehat (fair play), kejujuran, keterbukaan, dan keadilan. Dalam konteks ini, pemerintah juga harus menjadi al-muhtasib yang memiliki wewenang luas dalam mencegah dan menyelesaikan kasus-kasus pelanggaran nilai-nilai ini.

- Menjaga agar pasar hanya menyediakan barang dan jasa. Barang dan jasa untuk kemewahan dan bersenang-senang akan sangat dibatasi bahkan dilarang seandainya terdapat kebutuhan mendesak terhadap barang-barang primer.

Untuk itu, pemerintah harus membuat perencanaan pasar yang berbasiskan prioritas kebutuhan dan mengarahkan para pelaku pasar untuk memenuhi perencanaan ini. Pemerintah juga dapat bertindak sebagai pelaku pasar aktif (produsen) untuk menyediakan kebutuhan-kebutuhan sesuai dengan prioritas syariah dan kepentingan nasional. Sedangkan peran pemerintah yang khusus berkaitan dengan mekanisme pasar adalah sebagai berikut $:^{10}$

1. Secara umum memastikan dan menjaga agar mekanisme pasar dapat bersaing dengan sempurna. Pemerintah harus menjamin kebebasan masuk dan keluar pasar, menghilangkan berbagai hambatan dalam

${ }^{10}$ Havis Aravik, Sejarah Pemikiran Ekonomi Islam Kontemporer (Cet. I; Palembang: Kencana, 2017), h. 112. 
persaingan seperti monopoli, menyediakan informasi, membongkar penimbunan, melarang kartel-kartel yang merugikan dan lain-lain.

2. Membuat berbagai langkah untuk meningkatkan daya saing dan daya beli dari para pelaku pasar yang lemah, misalnya produsen kecil dan konsumen miskin.

3. Mengambil berbagai kebijakan untuk menciptakan harga yang adil, terutama seandainya persaingan yang sempurna tidak dimungkinkan terjadi pada pasar.

Monopoli tidak selalu akan berdampak buruk bagi masyarakat seandainya harga yang dihasilkan tetap merupakan harga yang adil. Dalam menjalankan perannya, pemerintah mempunyai beberapa instrumen kebijakan, antara lain sebagai berikut :

1. Manajemen produksi dan ketenagakerjaan di sektor publik. Pemerintah dapat berperan efektif dalam mengelola kekayaan publik. Mengatur produksi dan ketenagakerjaan pada sektor ini dapat mempunyai pengaruh besar dalam perekonomian secara keseluruhan.

2. Instrumen yang berkaitan dengan upaya mendorong. kegiatan sektor swasta, misalnya menetapkan regulasi bagi sektor swasta, melakukan redistribusi faktor produksi, al-hisbah, perlindungan bagi masyarakat lemah.

3. Pricing policy, di mana negara meregulasi harga dengan cara intervensi pasar, penetapan harga, atau mendorong kebijakan diskriminasi harga 
untuk kelompok masyarakat daerah. Pricing policy ini juga perlu dilakukan ketika pasar tidak dapat bersaing sempurna sehingga harga yang dihasilkan tidak merugikan masyarakat.

4. Kebijakan fiskal, yaitu pengelolaan APBN disesuaikan dengan prinsipprinsip keuangan publik Islam.

5. Kebijakan pembiayaan dan moneter.

6. Investasi kekayaan dan surplus sektor publik. 


\section{BAB III}

\section{PENUTUP}

\section{A. Kesimpulan}

Pasar adalah sebuah mekanisme pertukaran produk baik berupa barang maupun jasa yang alamiah dan telah berlangsung sejak peradaban awal manusia. Islam menempatkan pasar pada kedudukan yang penting dalam perekonomian. Rasulullah sangat menghargai harga yang dibentuk oleh mekanisme pasar sebagai harga yang adil. Beliau menolak adanya suatu intervensi harga seandainya perubahan harga terjadi karena mekanisme pasar yang wajar yaitu hanya karena pergeseran permintaan dan penawaran.

Pasar luar negeri yang dikunjungi Rasulullah Saw ketika masih berusia 12 tahun terletak di Bushra atau Bashrah, sebuah negara yang bernama Syam. Perjalanan ini dilakukan pada 582 Masehi mengikuti pamannya Abu Thalib. Hubungan antara Syam dan Jazirah Arab tidak pernah putus dari waktu ke waktu yang secara umum selalu fokus dalam bidang perdagangan, juga ekspor impor untuk berbagai bahan makanan dan hasil industri pokok masyarakat. Jalur Hijaz Syam adalah jalur terpenting yang dipadati oleh kafilah-kafilah dagang yang bolak balik membawa barang dagangan mereka dari negeri satu ke negeri lainnya. Jelas bahwa pasar memegang peranan dalam perekonomian masyarakat muslim pada masa Rasulullah Saw. 
Ada beberapa ulama klasik yang pernah membahas tentang ekonomi Islam dalam hal mekanisme pasar diantaranya Abu Yusuf, Ibnu Taimiyah, Ibnu Khaldun dan Al Ghazali.

Peranan pemerintah sangat penting untuk lebih menjamin berjalannya mekanisme pasar secara sempurna. Peran pemerintah dalam pasar ini secara garis besar dapat diklasifikasikan menjadi dua bagian, yaitu:

1. peran yang berkaitan dengan implementasi nilai dan moral Islam

2. Peran yang berkaitan dengan teknis operasional mekanisme pasar.adapun yang menjadi contoh peran pemerintah yang berkaitan dengan implementasi moralitas Islam adalah sebagai berikut;

a. Memastikan dan menjaga implementasi nilai dan moral

b. Islam secara keseluruhan Memastikan dan menjaga agar pasar hanya memperjualkan belikan barang dan jasa yang halal.

c. Melembagakan nilai-nilai persaingan yang sehat (fair play), kejujuran, keterbukaan, dan keadilan. Dalam konteks ini, pemerintah juga harus menjadi al-muhtasib yang memiliki wewenang luas dalam mencegah dan menyelesaikan kasuskasus pelanggaran nilai-nilai ini.

d. Menjaga agar pasar hanya menyediakan barang dan jasa. Barang dan jasa untuk kemewahan dan bersenang-senang akan sangat dibatasi bahkan dilarang seandainya terdapat kebutuhan mendesak terhadap barang-barang primer. 


\section{B. Saran}

Setelah Kami menyelesaikan makalah ini, menurut kami mekanisme pasar Islami, sangat memiliki peran yang penting dalam mencapai kesejahteraan masyarakat. Apalagi kondisi yang akan datang dipenuhi dengan tantangan. Diharapkan pemerintah mampu menerapkan apa yang telah di contohkan Rasulullah SAW mengenai mekanisme pasar. 


\section{DAFTAR PUSTAKA}

Alang, A. Z. (2018). Mekanisme Pasar Dalam Perspektif Ekonomi Islam. Institution And Sharia Finance, 1(2), 31-55.

Aravik, H. (2017). Sejarah Pemikiran Ekonomi Islam Kontemporer. Palembang: Kencana.

Fauziah, I. Y., \& Riyadi, A. K. (2013). Prinsip Dasar Ekonomi Islam Prespektif Maqashid al-syariah. Sidoarjo: Kencana.

Ghofur, A. (2017). Pengantar Ekonomi Syariah Konsep Dasar, Paradigma, Pengembangan Ekonomi Syariah. Kaliwungu: Rajawali Pers.

Karim, A. A. (2014). Ekonomi Mikro Islam. Jakarta: Rajawali Pers.

Muhammad. (2016). Ekonomi Mikro Islam. Yogyakarta: BPFE.

Mujahidin, A. (2013). Ekonomi Islam Sejarah, Konsep, Instrumen, Negara Dan Pasar. Jakarta: Rajawali Pers.

Nasution, Y. S. (2018). Mekanisme Pasar Dalam Perspektif Ekonomi Islam. AtTawassuth, 3(1), 1-22.

Rasti, A. (2020). Peran Pemerintah Dalam Mengawasi. Ekonomi Syariah, 1-12.

Zainal, V. R., Huda, N., Ekawati, R., \& Riorini, S. V. (2018). Ekonomi Mikro Islam. Jakarta: Bumi Aksara. 